\title{
Associations of Pantoea with Rice Plants: As Friends or Foes?
}

\author{
Febri Doni ${ }^{1}$ (D), Nurul Shamsinah Mohd Suhaimi ${ }^{2}$ (D), Budi Irawan ${ }^{1}$, Zulqarnain Mohamed ${ }^{2}$ \\ and Muhamad Shakirin Mispan 2,3,* \\ 1 Department of Biology, Faculty of Mathematics and Natural Sciences, Universitas Padjadjaran, \\ Jatinangor 45363, West Java, Indonesia; febri@unpad.ac.id (F.D.); budi.irawan@unpad.ac.id (B.I.) \\ 2 Institute of Biological Sciences, Faculty of Science, Universiti Malaya, Kuala Lumpur 50603, Malaysia; \\ nurull@um.edu.my (N.S.M.S.); zulq@um.edu.my (Z.M.) \\ 3 Centre for Research in Biotechnology for Agriculture (CEBAR), Universiti Malaya, \\ Kuala Lumpur 50603, Malaysia \\ * Correspondence: shakirin@um.edu.my
}

Citation: Doni, F.; Suhaimi, N.S.M.; Irawan, B.; Mohamed, Z.; Mispan, M.S. Associations of Pantoea with Rice Plants: As Friends or Foes? Agriculture 2021, 11, 1278. https://doi.org/ 10.3390 /agriculture11121278

Academic Editors: Beatrice Berger and Matthias Becker

Received: 14 November 2021 Accepted: 12 December 2021 Published: 16 December 2021

Publisher's Note: MDPI stays neutral with regard to jurisdictional claims in published maps and institutional affiliations.

Copyright: (C) 2021 by the authors. Licensee MDPI, Basel, Switzerland. This article is an open access article distributed under the terms and conditions of the Creative Commons Attribution (CC BY) license (https:// creativecommons.org/licenses/by/ $4.0 /)$.

\begin{abstract}
Pantoea species are gram-negative bacteria from the Enterobacteriaceae family, generally associated with plants, either as epiphytes or as pathogens. In the last decade, Pantoea species are being regarded as re-emerging pathogens that are the causal agents of various diseases in rice plants. Inherently, they are also known to be opportunistic plant symbionts having the capacity to enhance systemic resistance and increase the yield of rice plants. It is unclear how they can express both beneficial and pathogenic traits, and what factors influence and determine the outcome of a particular Pantoea-rice plant interaction. This review aims to compare the characteristics of rice plant-beneficial and pathogenic strains belonging to the Pantoea species and gain new insights, enabling distinction among the two types of plant-microbe interactions.
\end{abstract}

Keywords: Pantoea; rice; microbiome; symbiosis; plant-microbe interactions

\section{Introduction}

Phytobiomes consist of plants, their environment, and associated communities of macro and microorganisms. These networks of interactions profoundly influence plant and agroecosystem health and productivity [1,2]. Plants are highly dependent on associated microbes, as these microorganisms can support their development and provide protection against negative effects of harsh environments [3]. Over the millennia, plants became adapted to the presence of soil microbes and developed unique interactions with them to obtain resources for plant development and exploit their presence towards successful colonization of terrestrial systems [4]. This highly diverse group of microbes positively influences plant growth and productivity through increasing overall fitness. This may be achieved by conferring abiotic and biotic stress tolerance, enhancing growth, and decreasing water consumption, or fitness may also be increased by enhancing physiological and genetic characteristics $[5,6]$.

One biologically diverse and ecologically significant group of plant-associated bacteria that has recently captured the attention of researchers worldwide is the genus Pantoea $[7,8]$. The ubiquity, versatility and genetic tractability of Pantoea makes it an ideal group for not only exploring niche-specific adaptation and opportunism, but also for the development of various agricultural and environmental products $[9,10]$. Much of the early findings indicated that Pantoea is a plant pathogen, shown to exhibit parasitism with some agriculturally important crops [11,12].

Recent evidence has provided additional support, where the Pantoea species have re-emerged as a threat to global rice production as they have been shown to cause various rice diseases in several rice growing areas of the world [13,14]. In addition, studies under different agroecosystem conditions have also indicated that many Pantoea species caused 
leaf blight disease that severely impacted the rice farming system worldwide, and yield loss due to Pantoea infestation can be up to $70 \%$ in susceptible rice varieties [15].

Interestingly, in contrast to the claims mentioned above, there have also been research reports emerging of late that shed a positive light of the Pantoea association with rice plants [16-18]. Many species of Pantoea have been extensively investigated for their role as growth promoters, biological control agents, and enhancers of broad-spectrum resistance towards biotic and abiotic stresses $[19,20]$.

Reports of these opposing roles by Pantoea have resulted in the notion that perhaps Pantoea bears the capacity to switch their lifestyle from being pathogenic to non-pathogenic, or even beneficial to rice plants. However, the exact mechanisms on how this can be achieved remains unclear. In reality, Pantoea species exist along a continuum of lifestyles [7]. It is also unclear what determines the outcome of a particular Pantoea-rice plant interaction and which factors enable rice plants to distinguish beneficial species of Pantoea from pathogenic species of Pantoea. Thus, this review aims to compare rice plant-beneficial and pathogenic strains belonging to the genus Pantoea to get new insights, aiding in the distinction between the two types of plant-microbe interactions. While several distinct interaction strategies of Pantoea with the host plant have been described and are understood (e.g., [21,22]), less is known about how they fit into phytobiomes of rice plants, where beneficial microbes and pathogens interact in a complex relationship that involves entire microbial communities and environmental factors.

\section{Classification and Biology of Pantoea Species}

The Pantoea species are generally recognized as non-encapsulated, non-spore-forming gram-negative bacteria from the Enterobacteriaceae family [23]. Before 1989, pathogenic bacteria from this order belonged to a single genus known as Erwinia. The genus Pantoea was proposed based on differential sequence in the DNA hybridization group separating them from Erwinia [24]. Currently, there are 25 described species and two subspecies that belong to this genus that have been isolated from various environments such as water, soil, human, animals, and plants $[7,9,23]$.

Most species in the Pantoea genus are observed to have yellowish pigment, gramnegative cell wall, rod-shaped, peritrichous flagella and possess facultative anaerobic metabolism [25-28]. They show negative reactions towards oxidation, arginine dihydrolase, citrate utilization, sorbitol fermentation and nitrate test. On the other hand, these species are positive for catalase, gelatine and starch hydrolysis tests [29-31]. Bacteria from this genus are also capable of exhibiting acid production from various carbon sources such as maltose, trehalose, palatinose and L-arabinose [32].

Pantoea species can grow in a wide range of $\mathrm{pH}$ from 2 to 8 , with optimum growth occurring at $\mathrm{pH}$. The optimum growth temperature was at a range of $28^{\circ} \mathrm{C}$ to $30^{\circ} \mathrm{C}$ and the bacteria had been documented to tolerate a wide range of temperatures, from $4{ }^{\circ} \mathrm{C}$ to $41^{\circ} \mathrm{C}$. Additionally, optimal growth rate may be achieved when $\mathrm{NaCl}$ concentration is between 100-300 mM [30,33].

Multilocus Sequence Analysis (MLSA) using marker genes such as $23 \mathrm{~S}$ rRNA, rpoB, gyrB, and dnaK are often used for the exploration of the sequence discontinuities among the Pantoea species [23]. Sequence variations within housekeeping genes such as leuS, fusA, gyrB, rpoB, rlpB, infB, and atpD have also been used routinely to refine interspecific phylogenetic positions of species from the genus Pantoea [23,34].

Another strategy to resolve identification of Pantoea specimens is the use of a mass spectrometry-based approach, namely the matrix-assisted laser desorption ionization-time of flight (MALDI-TOF). Unfortunately, it has been reported that $24 \%$ of Pantoea species had been misidentified using this approach [35], which appears to suggest that a multiple gene sequencing strategy or whole genome-based identification methods are more reliable and accurate for Pantoea identification. 


\section{Beneficial Impacts of Pantoea-Rice Plant Interactions}

Generally, the existence of symbiotic relationships between plants and microbes is nothing new and has been well documented [36]. Although initially symbiotic microorganisms were considered to be neutral regarding their effects on host plants, recent evidence that points towards their positive impact on plant growth and development has been verified in a broad range of crops [37]. Direct plant growth promotion by microbes is based on improved nutrient acquisition, hormonal stimulation and alteration of physiological and genetic make-up. Indirectly, they may also reduce microbial populations that are harmful to the plant, acting as agents of biological control through competition, antibiosis, or systemic resistance induction [38].

Various studies on the Pantoea species have indeed shown that they possess many beneficial traits that could be used in rice farming systems such as combating rice plant pathogens and promoting growth and fitness [39]. As a matter of fact, members of the genus Pantoea are frequently detected around rice rhizosphere [40], on rice phyllosphere [41], inside rice plant tissues [42-44], and on rice seeds [45]. These enormous potentials serve only to suggest that perhaps it would be possible to develop Pantoea inoculants for use in sustainable rice production in the future.

\subsection{Impacts on Rice Plant Growth and Yield}

Reports from more than a decade ago have suggested that the inoculation of Pantoea to rice plants promoted rice plant development and yield. Zhang et al. [46] reported that the application of P. agglomerans to rice plants could enhance several growth parameters such as leaf growth, root elongation, root hair growth and stem growth. Furthermore, under the agroecosystem of southern Spain, Megías et al. [40,47] revealed that P. ananatis when applied to rice plants showed plant growth-promoting attributes, including the capacity to synthesize siderophores, cellulose, indole acetic acid (IAA) and 14 different molecules of N-acyl-homoserine-lactones (HSLs). Subsequently, inoculation of rice plants with $P$. ananatis significantly increased plant growth and crop yield by $60 \%$, indicating a high potential for its use as a commercial inoculant. More recently, a study by Sun et al. [39] showed that inoculation of P. alhagi in rice plants increased fresh weight, root length, and shoot length of rice plants compared with control plants.

\subsection{Impacts on Rice Plant Physiology}

In addition to increased growth and yield, rice plant physiology can also be improved in the presence of Pantoea species. When P. agglomerans was applied, the P content in rice plants was significantly increased in comparison to control plants [48]. Also, inoculation of rice plants with P. agglomerans significantly enhanced the transportation of the photosynthetic assimilation product from the source (flag leaves) to the sink (stachys) when compared to control plants [43]. This result indicated a superior metabolism capacity inside the plant cells following the exposure to Pantoea. Furthermore, Sun et al. [17,39] reported that colonization of rice roots by $P$. alhagi recorded a $26.3 \%$ increase in chlorophyll content, as well as up-regulated expression of proline synthase, a down-regulated expression of proline dehydrogenase, and enhanced antioxidant enzyme activities compared with uninoculated plants.

\subsection{Alleviation of Biotic Stress}

Association of rice plants with different strains of Pantoea improved their ability to withstand biotic stress. For example, $P$. ananatis had been shown to be antagonistic to the plant pathogen Xanthomonas spp., resulting in an improved rice plant survival [40,47]. In another example, P. ananatis showed a significant biological control efficacy (more than $50 \%$ ) towards rice blast caused by Magnaporthe grisea in greenhouse and field experiments. This evident decrease in the M. grisea severity in greenhouse and field experiments was attributed to the ability of $P$. ananatis to secreting extracellular hydrolytic enzymes [49]. Similarly, when rice plant roots were pre-treated with P. agglomerans prior to infection by 
fungal pathogen $M$. oryzae, the number of blast lesions in rice caused by M. oryzae was reduced. Further characterisation showed that the defence response elicited in rice by P. agglomerans is mediated through jasmonic acid and ethylene signalling pathways [50].

\subsection{Induction of Abiotic Stress Tolerance}

Root colonization by the Pantoea species induces systemic abiotic tolerance in plants. Early studies by Zeng et al. [51] indicated that P. agglomerans could stimulate the growth of rice plants under poor soil conditions. In their report, it was noted that rice plants associated with P. agglomerans grew much better compared to uninoculated control plants in lownutrient soils. Later, Bhise and Dandge [16] reported a significant improvement in plant growth supplemented with $P$. agglomerans inoculum in terms of increased length, biomass, photosynthetic pigment, and decreased level of proline and malondialdehyde under salt stress conditions. Inoculated plants also exhibited decreased sodium and increased calcium and potassium uptake. In a related study, Sun et al. [17] revealed that colonization of rice plants by $P$. alhagi increased salt resistance of rice through increasing the $\mathrm{K}^{+} / \mathrm{Na}^{+}$ ratio, antioxidant enzyme activities and proline content, and decreasing malondialdehyde content. Moreover $P$. ananatis ameliorated the oxidative stress in rice induced by $\mathrm{NaCl}$ and $\mathrm{Na}_{2} \mathrm{CO}_{3}$ treatment. The malondialdehyde content and various antioxidant enzyme activities decreased upon $P$. ananatis inoculation in salt-affected rice plants [18]. Recently, Ghosh et al. [52] reported the ability of $P$. dispersa in enhancing rice seedling growth with a simultaneous reduction in arsenic uptake, and ethylene levels in plants.

Another report by Sun et al. [39] revealed that foliar spray of exopolysaccharide (EPS) that had been derived from P. alhagi to rice plants was able to increase drought resistance of rice. Further analysis showed that malondialdehyde content in rice tissue was reduced while total chlorophyll, proline and soluble sugar content were enhanced. The researchers also noted that the activity of antioxidant enzymes- superoxide dismutase, peroxidase, and catalase, also significantly increased.

All of the studies discussed above indicated that Pantoea species could be used as effective biocontrol agents for various rice diseases. Previous studies also highlighted the capacity of Pantoea species in improving rice plant's tolerance towards abiotic stress, thereby contributing to better plant growth and yield. The efficacy of applying Pantoea inoculants in rice production has become more evident every year. However, more studies on the understanding of the capability of Pantoea species in enhancing rice plant development and the mechanisms involved are needed for acquiring maximum benefits from their application.

\section{Detrimental Impacts of Pantoea-Rice Plant Interactions Leading to Rice Diseases}

As mentioned previously, despite displaying beneficial roles in association with their host plants, Pantoea species had recently been regarded as a re-emerging pathogen based on the increasing number of reports of their involvement in diseases occurring in rice plants worldwide. Of the twenty-five known species that belong to the genus of Pantoea, some species have been reported as associated with rice diseases and they include $P$. dispersa, P. agglomerans, P. stewartii, P. wallisii and P. ananatis [15]. As early as 1983, a study by Azegami [53] indicated that the palea browning disease of rice in Japan was caused by Erwinia herbicola (E. herbicola was later known as P. agglomerans). A few years later, in 1986, Kim et al. [54] reported another case of brown discoloration of inner palea of rice occurring at the experimental field of Chonnam Provincial Rural Development Administration, Korea. The pathogenic bacterium was again identified as E. herbicola. According to an early observation by Tabei et al. [55], E. herbicola entered the lemmata and paleae through the stomata and multiplied in the intercellular space of the parenchyma. Stomata are mainly open on the inner surface of lemmata and paleae, a few on the outer surface of lemmata, and connected through the intercellular space of parenchyma.

In 2002, $P$. ananatis was described for the first time as the causative agent of stem necrosis disease in rice. The symptoms were characterized by necrotic lesions on the rachis 
and stem, extending into the flag leaf sheath and stopping at the second node. Another symptom observed was a fine 'mottling' of brown and green tissue above and below the top node, which subsequently affected the grain quality [56].

Pantoea species can also cause rice seeds to lose their viability as reported by Brazilian researchers. The pathogens were isolated from seed embryos by aseptically removing the seed coat and the bacterium was subsequently identified as P. agglomerans. It was also found that seeds associated with $P$. agglomerans when grown in a greenhouse for multiplication purposes showed poor or no germination [57]. Another report in China revealed that $P$. ananatis was able to cause severe discoloration of rice grains. Initially, at early flowering stage, some water-soaked lesions appeared on the lemma or palea, which would then turn brown in infected plants. These resulted in immature and lighter grains on panicles at harvest stage [58]. Grain discoloration disease associated with P. ananatis was also detected in Primorsky Krai, Russia. During the harvest season, bacterial yellow ooze was observed on panicles of infected rice plants, and the harvested grains were mostly immature and empty [30].

A more recent observation made in various rice cultivation systems in Asia, America, Africa and Europe was that the association of Pantoea species and rice plants can cause severe leaf blight disease infections (Figure 1). Field survey conducted in Benin and Togo reported that the $P$. ananatis and $P$. stewartii-infected rice leaves showed orange-brown lesions on one or both halves of the leaf blade $[59,60]$. Another report from a Russian rice field indicated a water-soaked symptom that led to the brown coloration appearing on plants' lemma and resemble a typical leaf blight symptom caused by P. ananatis [30]. Rice plants in Venezuela which were colonized by P. agglomerans also showed leaf blight symptoms. The rice leaves appeared as yellow or brownish lesions and later become dry, illustrative of cell death [32].

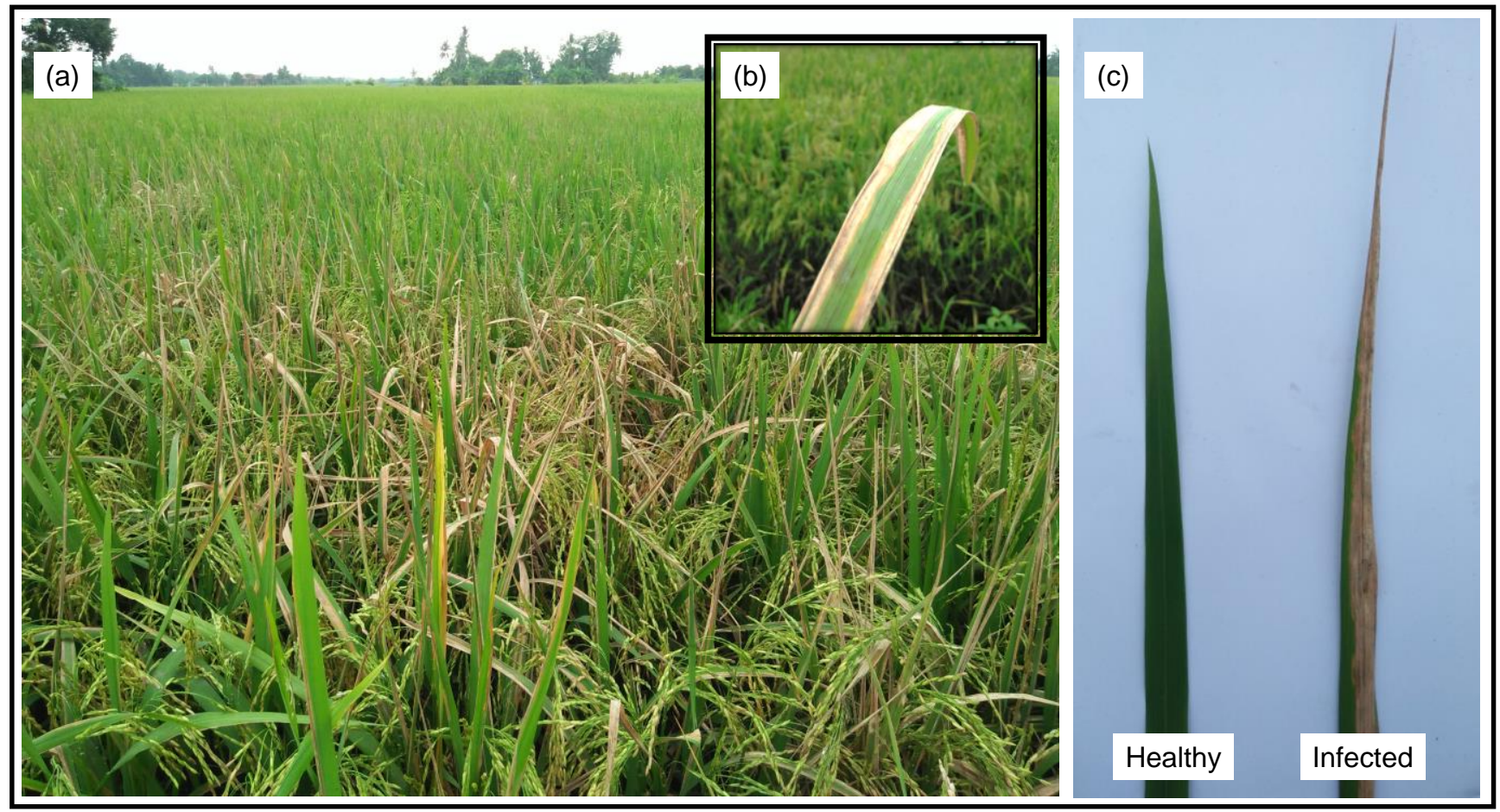

Figure 1. Leaf blight disease caused by Pantoea species in Selangor, Malaysia; (a) Highly infected rice field with a yellowish lesion on the leaves, (b) Close-up view of the infected leaf with a lesion at the edge, (c) Comparison between healthy leaf and leaf infected with the Pantoea species (Photos courtesy of Muhammad Nazri Ishak).

In the period of November-December 2017 of the second season of rice planting in Malaysia, several rice plots showed water-soaked lesions at the tip of the leaf and became brownish lines along the leaf margin. The causative pathogen was subsequently identified 
as $P$. stewartii [31]. Similar symptoms had also been detected in another local case at Selangor, Malaysia in 2016. The rice plants showed brownish lines along the leaf margins and eventually the entire leaf became dry [61]. Due to the reduction of the leaf area, the photosynthesis rate is affected, and this inadvertently led to reduced yield and quality of the rice grains. Arayaskul et al. [62] recently reported the first incidence of leaf blight associated with $P$. ananatis and $P$. stewartii in Thailand. The symptoms reported were similar to those made by other countries i.e., yellowish, light brown, to slightly reddish spots on leaves. Reports from various countries describing the rice diseases associated with Pantoea species are summarized in Table 1.

Table 1. Pantoea species associated with rice diseases.

\begin{tabular}{|c|c|c|c|c|}
\hline Countries & Causative Agents & Symptoms & Rice Diseases & References \\
\hline Malaysia & P. wallisii & $\begin{array}{l}\text { Water-soaked lesions at the tip of } \\
\text { the leaf and turning into brownish } \\
\text { lines along the leaf margin }\end{array}$ & Leaf blight & [15] \\
\hline China and Russia & P. ananatis & $\begin{array}{l}\text { Light, rusty, water-soaked lesions } \\
\text { appearing on the lemma or palea } \\
\text { and then turned brown }\end{array}$ & $\begin{array}{c}\text { Grain } \\
\text { discoloration }\end{array}$ & {$[30,58]$} \\
\hline $\begin{array}{l}\text { Malaysia, Turkey, Korea, } \\
\text { and Venezuela }\end{array}$ & P. agglomerans & $\begin{array}{l}\text { Water-soaked stripes or light } \\
\text { brown-to-slightly reddish spots on } \\
\text { the upper blades of the leaves }\end{array}$ & Leaf blight & {$[15,27,29,32]$} \\
\hline Japan, Korea, and China & P. agglomerans & $\begin{array}{c}\text { Brown discoloration of inner } \\
\text { glume (palea) }\end{array}$ & $\begin{array}{c}\text { Palea browning } \\
\text { disease }\end{array}$ & {$[53,54,63]$} \\
\hline Korea & P. ananatis & $\begin{array}{l}\text { Necrotic spot and brown } \\
\text { discoloration on glumes and stems } \\
\text { of rice }\end{array}$ & Sheath rot & {$[64]$} \\
\hline Italy & P. ananatis & $\begin{array}{l}\text { Light brown lesions, which, over } \\
\text { time, darkened, coalesced and } \\
\text { enlarged resulting in the uniform } \\
\text { browning of the palea }\end{array}$ & Palea browning & [65] \\
\hline $\begin{array}{l}\text { India, Benin, Malaysia, } \\
\text { Thailand, and Togo }\end{array}$ & P. stewartii & $\begin{array}{l}\text { Yellowing symptoms or one to two } \\
\text { orange or brown stripes on one or } \\
\text { both halves of the leaf blade }\end{array}$ & Leaf blight & {$[31,59,60,62,66]$} \\
\hline $\begin{array}{l}\text { India, Russia, Benin, } \\
\text { Togo, China, Turkey, } \\
\text { Thailand, and Malaysia }\end{array}$ & P. ananatis & $\begin{array}{l}\text { Water-soaked stripes with } \\
\text { yellowing color, which later } \\
\text { turned into brown stripes on the } \\
\text { upper part of leaves }\end{array}$ & Leaf blight & {$[26,28,30,59-62,67,68]$} \\
\hline Australia & P. ananatis & $\begin{array}{l}\text { Necrotic lesions occurring on the } \\
\text { rachis and stem, extending into } \\
\text { the flag leaf sheath and stopping at } \\
\text { the second node }\end{array}$ & Stem necrosis & [56] \\
\hline Brazil & P. agglomerans & $\begin{array}{l}\text { Little or slow germination of seed } \\
\text { Brownish stripes, which }\end{array}$ & Seed dormancy & [57] \\
\hline Malaysia & P. dispersa & $\begin{array}{l}\text { subsequently turn pale and dry on } \\
\text { leaf blades }\end{array}$ & Leaf blight & {$[61]$} \\
\hline
\end{tabular}

\section{Factors Affecting the Outcome of Pantoea-Rice Plant Interactions}

It has been generally known that Pantoea species form symbiotic associations with rice plants. The effects of Pantoea symbionts on rice fitness usually depend on several factors which include the particular Pantoea species, physiological status of rice plants, cultivation practices, and environmental conditions $[69,70]$. As mentioned earlier, in their natural habitats, rice plants and microbes interact in a complex scenario that involves entire microbial communities as well as influences from environmental factors. These interactions among the phytobiome members are highly regulated through a complex network of signaltransduction pathways [1]. Integration of knowledge of signalling mechanisms within these complex networks will lead to a further understanding of the fate and significance of these signals at the ecosystem level. 


\subsection{The Distinct Interaction Strategies of Pantoea with Host Plants}

An interesting study by Sheibani-Tezerji et al. [21] revealed that three closely related P. ananatis strains (named S6, S7, and S8) with highly similar genetic make-ups isolated from maize seeds of healthy plants exhibited distinct interaction strategies with maize from weak pathogenic (S7), commensal (S8), to a beneficial, growth-promoting effect (S6). Although closely related, several differences were noted in the genes encoding for proteins involved in the secretion system and their putative effectors, as well as genes related to transposase/integrases/phage functions. The three strains also differed in terms of the presence of hemolysin co-regulated effector proteins (Hcp), where the growth-promoting strain S6 possessed orthologs of the Hcp while the plant-pathogenic strain S7 do not. Protein studies confirmed the presence of the Hcp protein in S6, and absence in S7 and S8. Hcp protein is involved in bacterial motility, protease production and biofilm formation, and its role in determining the strains pathogenic/commensal/beneficial effect remains to be understood.

In another study, fifty $P$. ananatis strains collected from Georgia, US were investigated in relation to the genetic factors that correlated with their pathogenicity on different cultivated Allium species like onion, leek, shallot, and chive using MLSA and repetitive extragenic palindrome repeat (rep)-PCR techniques. The results revealed that the strains' interactions with various Allium species resulted in phenotypically diverse Allium infection phenotypes. The genomic analyses showed some distinct differences in terms of mobile genetic elements, and in Onion Virulence Regions (OVR) loci which differentiated the sequenced strains into two groups, that shared common scale-clearing and foliar pathogenicity phenotypes [71]. This transcriptional analysis of Pantoea with and without these loci may provide insights into the nature of this region contributions to distinction of interaction strategies of Pantoea with host plants, including with rice plants.

The transition of P. agglomerans from saprophytic to pathogenic lifestyles is primarily dependent on the acquisition of a plasmid-borne pathogenicity island (PAI) that harbours the hrp/hrc gene cluster [72]. In addition, the secretion of IAA and cytokinins by P. agglomerans is also capable of producing galls in various plants, through a mechanism which involved type III effectors [72,73]. More recently, Hofmeister et al. [22] investigated an $\mathrm{N}$-formylated sugar from the plant pathogenic vs. non-pathogenic of P. ananatis. The researchers utilized a simple bioinformatics analysis to determine whether any strains of $P$. ananatis contained the genes required to produce such carbohydrates. The results showed that those strains of $P$. ananatis that are pathogenic contained these genes, where the non-pathogenic apparently did not have. However, it is still unclear whether the presence of an N-formylated sugar on the O-antigen of a bacterium plays a role in virulence.

Pathogens are well recognized for deploying virulence factors that enable them to cause disease and inflict damage upon their host [74]. For example, bacterium P. stewartii utilizes an Hrp type III secretion system that produces needle-like injectisomes (pili) when infecting maize plants, thus enabling P. stewartii to inject an effector protein WtsE into the cytosol of maize plant cells that led to a disease associated with cell death $[75,76]$. In addition to an Hrp type III secretion system, known to be essential for plant pathogenesis, P. stewartii has a second type III secretion systems namely Pantoea secretion island 2 or T3SS PSI-2 which belongs to the Inv-MxiSpa T3SS family, typically found in animal pathogens [76]. Previously, Mor et al. [77] had characterized Hrp gene cluster from P. agglomerans in which it spans approximately $25 \mathrm{~kb}$ and contains seven complementation groups. Furthermore, Cao et al. [78] identified the yhfK gene from P. agglomerans that causes bacterial dry stalk disease. The study demonstrated that the yhfK affects pathogenicity of P. agglomerans, which is a critical element in the pathogenesis of P. agglomerans causing bacterial dry stalk.

\subsection{Receptors and Signalling Pathways for Recognition of Microbes in Rice Plants}

Rice plants interact with a wide range of microorganisms, including symbionts and pathogens. To discern beneficial microbes from pathogenic microbes, rice plants have employed various receptors that are able to recognize bioactive signals secreted by microor- 
ganisms $[79,80]$. Although the molecular studies on the crosstalk interaction between rice plants and Pantoea are still in a nascent stage, some studies on the molecular interactions between rice plants and other microbes have shown promising results. For example, rice receptor proteins (e.g., PRRs, FLS2 and LRR-RLKs) can recognize bioactive signals secreted by beneficial microbe Sinorhizobium meliloti 1021. Upon recognition and transduction of these bacterial signals, many differentially-expressed genes that are linked to TFs/PKs and enzymes for the regulation of growth and development such as GA, AUX, CK and BR are upregulated in rice seedlings. This recognition process subsequently upregulates large portion of genes that were involved in cycle regulator such as $\mathrm{CycA}, \mathrm{CycB}$ and $\mathrm{CycD} 1, \mathrm{D} 2$ and D3 which positively impacted and accelerated cell division. These cellular signalling enhancements led to the promotion of plant growth and development, photosynthesis capacity, phytohormone production, and other important traits in rice seedlings [81].

Moreover, $\mathrm{He}$ et al. [82] investigated the molecular association between arbuscular mycorrhizal fungi and rice plants. At first, mycorrhiza secreted Myc factors such as lipochitooligosaccharides (LCOs) and short-chain chitooligosaccharides (CO4/CO5) for initiating a mutualistic symbiosis with rice plants. Then, a LysM receptor heteromer OsMYR1/OsLYK2 and OsCERK1 in rice plants recognized the Myc factors secreted by mycorrhiza. However, a recent study by Zhang et al. [83] reported that $\mathrm{CO} 4$ and its receptor OsMYR1 were not only involved in initiating symbiotic signalling but also involved in reducing rice immunity by decreasing immune signalling induced by $\mathrm{CO} 8$, a bioactive immunity signal secreted by mycorrhiza. This study further indicates that a balanced perception of multiple symbiotic receptors in rice is important for the establishment of a successful mutualistic rice plant association with microbes (including Pantoea).

\subsection{Rice Cultivation Methods}

Rice plants that have been grown under agroecological methods are reported to be more resistant to plant diseases [84]. A study by Japanese researchers found that rice seedlings inoculated with Burkholderia glumae and B. plantarii (causal agents of bacterial seedling diseases) and cultivated under organic and conventional methods showed interesting results. The development of disease symptoms was significantly suppressed under organic method, but not under conventional method [85]. It has also been reported that rice plants grown under the System of Rice Intensification (SRI) method produce more robust rice plants that resist diseases such as sheath blight and leaf blight [84]. SRI is an agroecologically sound rice cultivation method that focuses on realizing the full genetic potential of the rice plants through practices that encourage the health of the whole plant and soil health $[86,87]$, as well as quality of macro-/micronutrient availability in soil and translocation to grains $[88,89]$.

Microbial activities in SRI rice fields were found to be more dynamic due to SRI creating such favourable conditions for microbes to thrive through applying organic amendments, aeration during weeding, and managing water carefully to create an aerobic soil condition [38]. Applying soil organic amendments in soil such as compost also induced the diversity and abundances of beneficial microbes therefore increasing the plant growth and disease tolerance [90].

Furthermore, rice plants grown under the SRI method exhibited lower lesion length, total lesion length and susceptibility index compared to rice plants grown under the conventional method when inoculated with Rhizoctonia solani (a causative agent of sheath blight disease in rice) [91]. This may be attributed to SRI plants possessing better physiological traits than those in the conventional method such as higher xylem exudation rates, deeper and more distributed root systems, higher water use efficiency, and higher rates of photosynthesis [92]. Overall, SRI enhances the resilience of plant systems to cope with diseases. 


\subsection{Involvement of Microbial Communities}

Plant microbiomes may have influenced their host plants positively or negatively. These microbial communities can protect plants from biotic stress via antagonistic effects against plant pathogens by producing antibiotics or secondary metabolites or by modulating the physiology of the host plants [93]. In this modern era, high-throughput sequencing such as next-generation sequencing and -omics technologies have revealed that plantassociated microbial communities are extensively involved in promoting the health and fitness of their host plants [94]. However, microbes can also compete with plants for water and nutrients, and some are phytopathogenic agents of many diseases [93].

Mendes et al. [93] and Raaijmakers et al. [95] suggested that restructuring the rhizospheric microbial communities by introducing beneficial microbes that protect the host plant against pathogen infections is somewhat similar to the use of probiotics in humans. Nevertheless, to attain efficient biocontrol effects, these beneficial microbes should be able to proliferate and survive in the rhizosphere and reach cell densities above a specific threshold. This phenomenon may adversely affect the population density, dynamics (temporal and spatial) and metabolic activities of soilborne pathogens via competition, antagonism and/or hyperparasitism that eventually influence the outcome of pathogen infection [95]. For example, a study indicated that higher diversity of microbial community in rice environs contributed significantly to the resistance of rice plants against $X$. oryzae $\mathrm{pv}$. oryzicola [96].

A recent study that explores the rice root microbiome composition in six different rice-producing regions in Ghana had proven that the structure of bacterial and fungal communities varied significantly between regions and that the local environmental factors influence the assembly of these community compositions [97]. These dynamic patterns of microbial structure in the soil therefore influence the below-ground and above-ground plants' development and fitness. Similarly, a study in China showed that soil microbiome contributes to an ultrahigh rice yield in Taoyuan region, and indicated that nitrogen metabolism functions employed by microbiome could be one of the mechanisms for the ultrahigh yield of rice [98]. The beneficial influence of cyanobacterial inoculation on the rice soil and plant microbiome illustrates the distinct interactions leading to robust plants [99], which can be resilient to abiotic and biotic stress. This further illustrates that the links between plant phenotypes and microbial networks in the soil could enable another promising approach for promoting plant production and protecting the host plants against detrimental microbial and non-microbial invaders.

\section{Conclusions}

Although Pantoea species have been consecutively identified as plant pathogens, there are many findings also indicated that not all Pantoea species seem to contribute to disease development in rice plants. In fact, several members of the genus have been potentially found to enhance growth and yield, control plant pathogenic microbes, and increase abiotic tolerance in rice plants. Many factors determine the outcome of a particular Pantoea-rice interaction, such as: (i) specific strains of Pantoea that harbour either beneficial or pathogenic traits, (ii) the fitness and physiological status of the rice plant, and (iii) the external factors such as environmental conditions and microbial community structures.

The phenomenon of how Pantoea species can express both beneficial and pathogenic traits suggests that the role of microbes in the plants' community structure and dynamics is very complex. Thus, more studies must be conducted in relation to the composition, diversity and functions of the plant microbiomes, to decipher the complexity of these interactions, and enable better plant vigor, health and productivity.

Author Contributions: Writing—original draft preparation: F.D.; Conceptualization: F.D.; writingreview and editing: F.D., M.S.M., B.I., Z.M., N.S.M.S.; supervision and project administration: F.D., N.S.M.S., Z.M., M.S.M.; visualization: F.D., M.S.M.; funding acquisition: M.S.M. All authors have read and agreed to the published version of the manuscript. 
Funding: This research was supported by the Fundamental Research Grant Scheme (FRGS), Ministry of Higher Education, Malaysia (Grant no. FRGS/1/2019/WAB01/UM/02/4).

Institutional Review Board Statement: Not applicable.

Informed Consent Statement: Not applicable.

Data Availability Statement: Not applicable.

Acknowledgments: The first author would like to thank the Universitas Padjadjaran for the support during the writing process. The authors express appreciation to Muhammad Nazri Ishak (Universiti Malaya) for assisting us during the field trial and providing us photos for this review article. The authors also express appreciation for the helpful comments and suggestions from Radha Prasanna and Gerry Bodeker.

Conflicts of Interest: The authors declare no conflict of interest.

\section{References}

1. Leach, J.E.; Triplett, L.R.; Argueso, C.T.; Trivedi, P. Communication in the phytobiome. Cell 2017, 169, 587-596. [CrossRef]

2. Snoeijenbos, M.; Cárdenas, M.; Guevara-Suarez, M.; Bernal, A.; Jiménez, P.; Restrepo, S. Phytobiomes, the reason why microbiologists and botanists should work together. In Annual Plant Reviews Online; Roberts, J.A., Ed.; Willey: Hoboken, NJ, USA, 2019.

3. Andreote, F.D.; de CássiaPereira e Silva, M. Microbial communities associated with plants: Learning from nature to apply it in agriculture. Curr. Opin. Microbiol. 2017, 37, 29-34. [CrossRef]

4. $\quad$ Rodriguez, R.J.; White, J.F., Jr.; Arnold, A.E.; Redman, R.S. Fungal endophytes: Diversity and functional roles. New Phytol. 2009, 182, 314-330. [CrossRef] [PubMed]

5. Porter, S.S.; Bantay, R.; Friel, C.A.; Garoutte, A.; Gdanetz, K.; Ibarreta, K.; Moore, B.M.; Shetty, P.; Siler, E.; Friesen, M.L. Beneficial microbes ameliorate abiotic and biotic sources of stress on plants. Funct. Ecol. 2020, 34, 2075-2086. [CrossRef]

6. Harman, G.; Khadka, R.; Doni, F.; Uphoff, N. Benefits to plant health and productivity from enhancing plant microbial symbionts. Front. Plant Sci. 2021, 11, 610065. [CrossRef]

7. Coutinho, T.A.; Venter, S.N. Pantoea ananatis: An unconventional plant pathogen. Mol. Plant Pathol. 2009, 10, 325-335. [CrossRef]

8. Soluch, R.; Hülter, N.F.; Romero, P.D.; Özkurt, E.; Stukenbrock, E.H.; Dagan, T. Colonization dynamics of Pantoea agglomerans in the wheat root habitat. Environ. Microbiol. 2021, 23, 2260-2273. [CrossRef] [PubMed]

9. Walterson, A.M.; Stavrinides, J. Pantoea: Insights into a highly versatile and diverse genus within the Enterobacteriaceae. FEMS Microbiol. Rev. 2015, 39, 968-984. [CrossRef]

10. Duron, O.; Noël, V. A wide diversity of Pantoea lineages are engaged in mutualistic symbiosis and cospeciation processes with stinkbugs. Environ. Microbiol. Rep. 2016, 8, 715-727. [CrossRef] [PubMed]

11. Cooksey, D. Galls of Gypsophila-paniculata caused by Erwinia herbicola. Plant Dis. 1986, 70, 464-468. [CrossRef]

12. Mergaert, J.; Verdonck, L.; Kersters, K. Transfer of Erwinia ananas (synonym, Erwinia uredovora) and Erwinia stewartii to the genus Pantoea emend. as Pantoea ananas (Serrano 1928) comb. nov. and Pantoea stewartii (Smith 1898) comb. nov., respectively, and description of Pantoea stewartii subsp. indologenes subsp. nov. Int. J. Syst. Bacteriol. 1993, 43, 162-173.

13. Azizi, M.M.F.; Ismail, S.I.; Ina-Salwany, M.Y.; Hata, E.M.; Zulperi, D. The emergence of Pantoea species as a future threat to global rice production. J. Plant Prot. Res. 2020, 60, 327-335.

14. Kini, K.; Lefeuvre, P.; Silué, D.; Koebnik, R. Genome resources of three West African strains of Pantoea ananatis causing bacterial blight and grain discoloration of rice. Phytopathology 2020, 110, 1500-1502. [CrossRef] [PubMed]

15. Doni, F.; Suhaimi, N.S.M.; Mohamed, Z.; Ishak, N.; Mispan, M.S. Pantoea: A newly identified causative agent for leaf blight disease in rice. J. Plant Dis. Prot. 2019, 126, 491-494. [CrossRef]

16. Bhise, K.K.; Dandge, P.B. Alleviation of salinity stress in rice plant by encapsulated salt tolerant plant growth promoting bacteria Pantoea agglomerans strain KL and its root colonization ability. Arch. Agron. Soil Sci. 2019, 65, 1955-1968. [CrossRef]

17. Sun, L.; Lei, P.; Wang, Q.; Ma, J.; Zhan, Y.; Jiang, K.; Xu, Z.; Xu, H. The endophyte Pantoea alhagi NX-11 alleviates salt stress damage to rice seedlings by secreting exopolysaccharides. Front. Microbiol. 2020, 10, 3112. [CrossRef]

18. Lu, L.; Chang, M.; Han, X.; Wang, Q.; Wang, J.; Yang, H.; Guan, Q.; Dai, S. Beneficial effects of endophytic Pantoea ananatis with ability to promote rice growth under saline stress. J. Appl. Microbiol. 2021, 131, 1919-1931. [CrossRef] [PubMed]

19. Chen, C.; Xin, K.; Liu, H.; Cheng, J.; Shen, X.; Wang, Y.; Zhang, L. Pantoea alhagi, a novel endophytic bacterium with ability to improve growth and drought tolerance in wheat. Sci. Rep. 2017, 7, 41564. [CrossRef]

20. Nascimento, F.X.; Hernandez, A.G.; Glick, B.R.; Rossi, M.J. The extreme plant-growth-promoting properties of Pantoea phytobeneficialis MSR2 revealed by functional and genomic analysis. Environ. Microbiol. 2020, 22, 1341-1355. [CrossRef] [PubMed]

21. Sheibani-Tezerji, R.; Naveed, M.; Jehl, M.A.; Sessitsch, A.; Rattei, T.; Mitter, B. The genomes of closely related Pantoea ananatis maize seed endophytes having different effects on the host plant differ in secretion system genes and mobile genetic elements. Front. Microbiol. 2015, 6, 440. [CrossRef] 
22. Hofmeister, D.L.; Thoden, J.B.; Holden, H.M. Investigation of a sugar N-formyltransferase from the plant pathogen Pantoea ananatis. Protein Sci. 2019, 28,707-716. [CrossRef]

23. Tambong, J.T. Taxogenomics and systematics of the genus Pantoea. Front. Microbiol. 2019, 10, 2463. [CrossRef]

24. Gavini, F.; Mergaert, J.; Beji, A.; Mielcarek, C.; Izard, D.; Kersters, K.; De Ley, J. Transfer of Enterobacter agglomerans (Beijerinck 1888) Ewing and Fife 1972 to Pantoea gen. nov. as Pantoea agglomerans comb. nov. and description of Pantoea dispersa sp. nov. Int. J. Syst. Evol. Microbiol. 1989, 39, 337-345. [CrossRef]

25. Roper, M.C. Pantoea stewartii subsp. stewartii: Lessons learned from a xylem-dwelling pathogen of sweet corn. Mol. Plant Pathol. 2011, 12, 628-637. [CrossRef]

26. Mondal, K.K.; Mani, C.; Singh, J.; Kim, J.G.; Mudgett, M.B. A new leaf blight of rice caused by Pantoea ananatis in India. Plant Dis. 2011, 95, 1582. [CrossRef]

27. Aksoy, H.M.; Boluk, E. First report of Pantoea agglomerans on Oryza sativa in Turkey. J. Plant Pathol. 2019, 101, 449. [CrossRef]

28. Aksoy, H.M.; Boluk, E. First report of Pantoea ananatis in japonia rice varieties in Turkey. J. Plant Pathol. 2019, 101, 409. [CrossRef]

29. Lee, H.B.; Hong, J.P.; Kim, S.B. First report of leaf blight caused by Pantoea agglomerans on rice in Korea. Plant Dis. 2010, $94,1372$. [CrossRef]

30. Egorova, M.; Mazurin, E.; Ignatov, A.N. First report of Pantoea ananatis causing grain discolouration and leaf blight of rice in Russia. New Dis. Rep. 2015, 32, 21. [CrossRef]

31. Azizi, M.M.F.; Ismail, S.I.; Md Yasin, I.S.; Mohd Hata, E.; Abdullah, M.A.F.; Zulperi, D. First report of Pantoea stewartii subspecies indologenes causing leaf blight on rice in Malaysia. Plant Dis. 2019, 103, 1407. [CrossRef]

32. González, A.D.; Franco, M.A.; Contreras, N.; Galindo-Castro, I.; Jayaro, Y.; Graterol, E. First report of Pantoea agglomerans causing rice leaf blight in Venezuela. Plant Dis. 2015, 99, 552. [CrossRef]

33. Silini-Cherif, H.; Silini, A.; Ghoul, M.; Yadav, S. Isolation and characterization of plant growth promoting traits of a rhizobacteria: Pantoea agglomerans lma2. Pak. J. Biol. Sci. 2012, 15, 267-276. [CrossRef]

34. Morin, A. Pantoea. Ency. Food Microbiol. 2014, 1028-1032. [CrossRef]

35. Soutar, C.D.; Stavrinides, J. Molecular validation of clinical Pantoea isolates identified by MALDI-TOF. PLoS ONE 2019, 14, e0224731. [CrossRef] [PubMed]

36. Rodriguez, R.; Redman, R. More than 400 million years of evolution and some plants still can't make it on their own: Plant stress tolerance via fungal symbiosis. J. Exp. Bot. 2008, 59, 1109-1114. [CrossRef]

37. Harman, G.; Doni, F.; Khadka, R.B.; Uphoff, N. Endophytic strains of Trichoderma increase plants' photosynthetic capability. J. Appl. Microbiol. 2021, 130, 529-546. [CrossRef]

38. Doni, F.; Mispan, M.S.; Suhaimi, N.S.M.; Ishak, N.; Uphoff, N. Roles of microbes in supporting sustainable rice production using the system of rice intensification. Appl. Microbiol. Biotechnol. 2019, 103, 5131-5142. [CrossRef] [PubMed]

39. Sun, L.; Yang, Y.; Wang, R.; Li, S.; Qiu, Y.; Lei, P.; Gao, J.; Xu, H.; Zhang, F.; Lv, Y. Effects of exopolysaccharide derived from Pantoea alhagi NX-11 on drought resistance of rice and its efficient fermentation preparation. Int. J. Biol. Macromol. 2020, 162, 946-955. [CrossRef]

40. Megías, E.; Junior, F.B.R.; Ribeiro, R.A.; Megías, M.; Ollero, F.J.; Hungria, M. Genome sequence of Pantoea sp. strain 1.19, isolated from rice rhizosphere, with the capacity to promote growth of legumes and nonlegumes. Genome Announc. 2017 , 5, e00707-e00717. [CrossRef]

41. Venkatachalam, S.; Ranjan, K.; Prasanna, R.; Ramakrishnan, B.; Thapa, S.; Kanchan, A. Diversity and functional traits of culturable microbiome members, including cyanobacteria in the rice phyllosphere. Plant Biol. 2016, 18, 627-637. [CrossRef]

42. Verma, S.C.; Singh, A.; Chowdhury, S.P.; Tripathi, A.K. Endophytic colonization ability of two deep-water rice endophytes, Pantoea sp. and Ochrobactrum sp. using green fluorescent protein reporter. Biotechnol. Lett. 2004, 26, 425-429. [CrossRef]

43. Feng, Y.; Shen, D.; Song, W. Rice endophyte Pantoea agglomerans YS19 promotes host plant growth and affects allocations of host photosynthates. J. Appl. Microbiol. 2006, 100, 938-945. [CrossRef]

44. Miao, Y.; Zhou, J.; Chen, C.; Shen, D.; Song, W.; Feng, Y. In vitro adsorption revealing an apparent strong interaction between endophyte Pantoea agglomerans YS19 and host rice. Curr. Microbiol. 2008, 57, 547-551. [CrossRef] [PubMed]

45. Wu, L.; Liu, R.; Niu, Y.; Lin, H.; Ye, W.; Guo, L.; Hu, X. Whole genome sequence of Pantoea ananatis R100, an antagonistic bacterium isolated from rice seed. J. Biotechnol. 2016, 225, 1-2. [CrossRef] [PubMed]

46. Zhang, X.; Li, E.; Xiong, X.; Shen, D.; Feng, Y. Colonization of endophyte Pantoea agglomerans YS19 on host rice, with formation of multicellular symplasmata. World J. Microbiol. Biotechnol. 2010, 26, 1667-1673. [CrossRef]

47. Megías, E.; Megías, M.; Ollero, F.J.; Hungria, M. Draft genome sequence of Pantoea ananatis strain AMG521, a rice plant growthpromoting bacterial endophyte isolated from the Guadalquivir marshes in southern Spain. Genome Announc. 2016, 4, e01681-15. [CrossRef] [PubMed]

48. Chung, H.K.; Ryu, J.H.; Lee, H.S.; Park, M.S.; Madhaiyan, M.; Seshadri, S.; Sa, T.M. Effect of immobilized cells of Pantoea agglomerans on growth promotion of rice (Oryza sativa L.) in the presence of rock phosphates. Korean J. Soil Sci. Fert. 2004, 37, $41-45$.

49. Tokpah, D.P.; Li, H.; Newmah, J.T.; Page, Z.; Luther, Z.; King, C.F.; Smith, M.S.; Voor, V.M. Biological control of potential antagonistic bacteria isolates to restrict Magnaporthe grisea infection on rice. Afr. J. Microbiol. Res. 2017, 11, 1108-1119.

50. Spence, C.; Alff, E.; Johnson, C.; Ramos, C.; Donofrio, N.; Sundaresan, V.; Bais, H. Natural rice rhizospheric microbes suppress rice blast infections. BMC Plant Biol. 2014, 14, 130. [CrossRef] 
51. Zeng, Q.G.; Luo, F.; Zhang, Z.B.; Yan, R.M.; Zhu, D. Phosphate solubilizing rhizosphere bacterial T21 isolated from Dongxiang wild rice species promotes cultivated rice growth. Appl. Mech. Mater. 2012, 108, 167-175. [CrossRef]

52. Ghosh, A.; Pramanik, K.; Bhattacharya, S.; Mondal, S.; Ghosh, S.K.; Ghosh, P.K.; Maiti, T.K. Abatement of arsenic-induced phytotoxic effects in rice seedlings by an arsenic-resistant Pantoea dispersa strain. Environ. Sci. Pollut. Res. 2021, 28, 21633-21649. [CrossRef]

53. Azegami, K. Bacterial palea browning, a new disease of rice caused by Erwinia herbicola. Bull. Natl. Inst. Agric. Ser. C 1983, 37, 1-2.

54. Kim, Y.C.; Kim, K.C.; Cho, B.H. Palea browning disease of rice caused by Erwinia herbicola and ice nucleation activity of the pathogenic bacterium. Korean J. Plant Pathol. 1989, 1, 72-79.

55. Tabei, H.; Azegami, K.; Fukuda, T. Infection site of rice grain with Erwinia herbicola, the causal agent of bacterial palea browning of rice. Ann. Phytopath. Soc. Jpn. 1988, 54, 637-639. [CrossRef]

56. Cother, E.J.; Reinke, R.; McKenzie, C.; Lanoiselet, V.M.; Noble, D.H. An unusual stem necrosis of rice caused by Pantoea ananas and the first record of this pathogen on rice in Australia. Australas. Plant Pathol. 2004, 33, 495-503. [CrossRef]

57. Filho, R.C.; Rodrigues, L.L.; Abreu, A.; Souza, R.R.; Rangel, P.H.N.; Mello, R.N.; Rocha, G.; Cunha, M. Detection of Pantoea agglomerans in germplasm Rice accessions (Oryza sativa) in Brazil. Plant Dis. 2018, 102, 237. [CrossRef]

58. Yan, H.; Yu, S.H.; Xie, G.L.; Fang, W.; Su, T.; Li, B. Grain discoloration of rice caused by Pantoea ananatis (synonym Erwinia uredovora) in China. Plant Dis. 2010, 94, 482. [CrossRef] [PubMed]

59. Kini, K.; Agnimonhan, R.; Afolabi, O.; Milan, B.; Soglonou, B.; Gbogbo, V.; Koebnik, R.; Silué, D. First report of a new bacterial leaf blight of rice caused by Pantoea ananatis and Pantoea stewartii in Benin. Plant Dis. 2017, 101, 242. [CrossRef]

60. Kini, K.; Agnimonhan, R.; Afolabi, O.; Soglonou, B.; Silué, D.; Koebnik, R. First report of a new bacterial leaf blight of rice caused by Pantoea ananatis and Pantoea stewartii in Togo. Plant Dis. 2017, 101, 241. [CrossRef]

61. Toh, W.K.; Loh, P.C.; Wong, H.L. First Report of leaf blight of rice caused by Pantoea ananatis and Pantoea dispersa in Malaysia. Plant Dis. 2019, 103, 1764. [CrossRef]

62. Arayaskul, N.; Poompouang, S.; Lithanatudom, P.; Lithanatudom, S.K. First report of a leaf blight in rice (Oryza sativa) caused by Pantoea ananatis and Pantoea stewartii in Thailand. Plant Dis. 2020, 104, 562. [CrossRef]

63. Guanlin, X.; Chuanyu, X.; Xiaoping, R. Characterization of pathogenic Pantoea agglomerans from rice seed. J. Zhejiang Univ. (Agric. Life. Sci.) 2021, 27, 317-320.

64. Choi, O.H.; Kim, H.Y.; Lee, Y.S.; Kim, J.W.; Moon, J.S.; Hwang, I.G. First report of sheath rot of rice caused by Pantoea ananatis in Korea. Plant Pathol. J. 2012, 28, 331. [CrossRef]

65. Cortesi, P.; Pizzatti, C. Palea browning, a new disease of rice in Italy caused by Pantoea ananatis. J. Plant Pathol. 2007, 89 (Suppl. 3), S76.

66. Vinodhini, J.; Kannan, R.; Sankareswari, R.U.; Akila, R.; Pillai, M.A. Characterization of new bacterial leaf blight of rice caused by Pantoea stewartii subsp. indologenes in southern districts of Tamil Nadu. Int. J. Environ. Agric. Biotechnol. 2017, 2, 3279-3284.

67. Azizi, M.M.F.; Abdul Rahman, M.A.; Ismail, S.I.; Md Yasin, I.S.; Mohd Hata, E.; Abdul Basir, B.; Othman, N.A.; Abdullah, M.A.F.; Zulperi, D. First report of Pantoea ananatis causing leaf blight disease of rice in peninsular Malaysia. Plant Dis. 2019, 103, 2122. [CrossRef]

68. Yu, L.; Yang, C.; Ji, Z.; Zeng, Y.; Liang, Y.; Hou, Y. First report of new bacterial leaf Blight of rice caused by Pantoea ananatis in Southeast China. Plant Dis. 2021. [CrossRef]

69. Manulis, S.; Barash, I. Pantoea agglomerans pvs. gypsophilae and betae, recently evolved pathogens? Mol. Plant Pathol. 2003, 4, 307-314. [CrossRef] [PubMed]

70. Brady, C.; Venter, S.; Cleenwerck, I.; Vancanneyt, M.; Swings, J.; Coutinho, T. A FAFLP system for the improved identification of plant-pathogenic and plant-associated species of the genus Pantoea. Syst. Appl. Microbiol. 2017, 30, 413-417. [CrossRef]

71. Stice, S.P.; Stumpf, S.D.; Gitaitis, R.; Kvitko, B.H.; Dutta, B. Pantoea ananatis genetic diversity analysis reveals limited genomic diversity as well as accessory genes correlated with onion pathogenicity. Front. Microbiol. 2018, 9, 184. [CrossRef]

72. Barash, I.; Manulis-Sasson, S. Virulence mechanisms and host specificity of gall-forming Pantoea agglomerans. Trends Microbiol. 2007, 15, 538-545. [CrossRef]

73. Manulis, S.; Haviv-Chesner, A.; Brandl, M.T.; Lindow, S.E.; Barash, I. Differential involvement of indole-3-acetic acid biosynthetic pathways in pathogenicity and epiphytic fitness of Erwinia herbicola pv. gypsophilae. Mol. Plant-Microbe Interact. 1998, 11, 634-642. [CrossRef]

74. Wiles, T.J.; Guillemin, K. The other side of the coin: What beneficial microbes can teach us about pathogenic potential. J. Mol. Biol. 2019, 431, 2946-2956. [CrossRef]

75. Ham, J.H.; Majerczak, D.R.; Arroyo-Rodriguez, A.S.; Mackey, D.M.; Coplin, D.L. WtsE, an AvrE-family effector protein from Pantoea stewartii subsp. stewartii, causes disease-associated cell death in corn and requires a chaperone protein for stability. Mol. Plant-Microbe Interact. 2006, 19, 1092-1102. [CrossRef]

76. Correa, V.R.; Majerczak, D.R.; Ammar, E.-D.; Merighi, M.; Pratt, R.C.; Hogenhout, S.A.; Coplin, D.L.; Redinbaugh, M.G. The bacterium Pantoea stewartii uses two different type III secretion systems to colonize its plant host and insect vector. Appl. Environ. Microbiol. 2012, 78, 6327-6336. [CrossRef] [PubMed]

77. Mor, H.; Manulis, S.; Zuc, M.; Nizan, R.; Coplin, D.L.; Barash, I. Genetic organization of the hrp gene cluster and dspAE/BF operon in Erwinia herbicola pv. gypsophilae. Mol. Plant-Microbe Interact. 2001, 14, 431-436. [CrossRef]

78. Cao, H.; Zhang, L.; Zhu, Z.; Wang, X.; Li, H.; Ren, Z. Cloning of a pathogenicity gene yhfK from Pantoea agglomerans on maize inbred line PS056. Sci. Agric. Sin. 2011, 44, 299-306. 
79. Böhm, H.; Albert, I.; Fan, L.; Reinhard, A.; Nürnberger, T. Immune receptor complexes at the plant cell surface. Curr. Opin. Plant Biol. 2014, 20, 47-54. [CrossRef]

80. Mishra, S.; Bhattacharjee, A.; Sharma, S. An ecological insight into the multifaceted world of plant-endophyte association. Crit. Rev. Plant Sci. 2021, 40, 127-146. [CrossRef]

81. Wu, Q.; Peng, X.; Yang, M.; Zhang, W.; Dazzo, F.B.; Uphoff, N.; Jing, Y.; Shen, S. Rhizobia promote the growth of rice shoots by targeting cell signaling, division and expansion. Plant Mol. Biol. 2018, 97, 507-523. [CrossRef]

82. He, J.; Zhang, C.; Dai, H.; Liu, H.; Zhang, X.; Yang, J.; Chen, X.; Zhu, Y.; Wang, D.; Qi, X.; et al. A LysM receptor heteromer mediates perception of arbuscular mycorrhizal symbiotic signal in rice. Mol. Plant 2019, 12, 1561-1576. [CrossRef]

83. Zhang, C.; He, J.; Dai, H.; Wang, G.; Zhang, X.; Wang, C.; Shi, J.; Chen, X.; Wang, D.; Wang, E. Discriminating symbiosis and immunity signals by receptor competition in rice. Proc. Nat. Acad. Sci. USA 2021, 118, e2023738118. [CrossRef]

84. Thakur, A.K.; Uphoff, N.; Stoop, W.A. Scientific underpinnings of the System of Rice Intensification (SRI): What is known so far? Adv. Agron. 2016, 135, 147-179.

85. AAndo, S.; Ito, T.; Kanno, T.; Kobayashi, T.; Morikawa, T.; Honda, K.I.; Tsushima, S.; Takahashi, H. Impact of organic crop management on suppression of bacterial seedling diseases in rice. Org. Agric. 2014, 4, 187-196. [CrossRef]

86. Thakur, A.K.; Uphoff, N. How the System of Rice Intensification contributes to climate-smart agriculture. Agron. J. 2017, 109, 1163-1182. [CrossRef]

87. Thakur, A.K.; Mandal, K.G.; Mohanty, R.K.; Uphoff, N. How agroecological rice intensification can assist in reaching the Sustainable Development Goals. Int. J. Agric. Sustain. 2021, 1-15. [CrossRef]

88. Adak, A.; Prasanna, R.; Babu, S.; Bidyarani, N.; Verma, S.; Pal, M.; Shivay, Y.S.; Nain, L. Micronutrient enrichment mediated by plant-microbe interactions and rice cultivation practices. J. Plant Nutr. 2016, 39, 1216-1232. [CrossRef]

89. Prasanna, R.; Adak, A.; Verma, S.; Bidyarani, N.; Babu, S.; Pal, M.; Shivay, Y.S.; Nain, L. Microbial inoculation in rice grown under flooded and SRI modes of cultivation elicits differential effects on plant growth and nutrient dynamics. Ecol. Eng. 2015, 84, 532-541. [CrossRef]

90. Brenzinger, K.; Costa, O.Y.A.; Ho, A.; Koorneef, G.; Robroek, B.; Molenaar, D.; Korthals, G.; Bodelier, P.L.E. Steering microbiomes by organic amendments towards climate-smart agricultural soils. Biol. Fertil. Soils 2021, 57, 1053-1074. [CrossRef]

91. Doni, F. Trichoderma asperellum SL2 for Improving Growth, Gene Expression Pattern, Physiological Traits, Yield and Disease Resistance of Rice Plants under System of Rice Intensification (SRI) Management System. Ph.D. Thesis, The National University of Malaysia, Bangi, Malaysia, 2018.

92. Thakur, A.K.; Uphoff, N.; Antony, E. An assessment of physiological effects of system of rice intensification (SRI) practices compared with recommended rice cultivation practices in India. Exp. Agric. 2010, 46, 77-98. [CrossRef]

93. Mendes, R.; Garbeva, P.; Raaijmakers, J.M. The rhizosphere microbiome: Significance of plant beneficial, plant pathogenic, and human pathogenic microorganisms. FEMS Microbiol. Rev. 2013, 37, 634-663. [CrossRef]

94. Kim, H.; Lee, Y.H. The rice microbiome: A model platform for crop holobiome. Phytobiomes J. 2020, 4, 5-18. [CrossRef]

95. Raaijmakers, J.M.; Paulitz, T.C.; Steinberg, C.; Alabouvette, C.; Moënne-Loccoz, Y. The rhizosphere: A playground and battlefield for soilborne pathogens and beneficial microorganisms. Plant Soil 2009, 321, 341-361. [CrossRef]

96. Yang, J.; Dai, Z.; Wan, X.; Munir, S.; Wang, X.; Wei, L.; Ji, G. Insights into the relevance between bacterial endophytic communities and resistance of rice cultivars infected by Xanthomonas oryzae pv. oryzicola. 3 Biotech 2021, 11, 1-12. [CrossRef] [PubMed]

97. Kanasugi, M.; Sarkodee-Addo, E.; Omari, R.A.; Dastogeer, K.M.G.; Fujii, Y.; Abebrese, S.O.; Bam, R.; Asuming-Brempong, S.; Okazaki, S. Exploring rice root microbiome; the variation, specialization and interaction of bacteria and fungi in six tropic savanna regions in Ghana. Sustainability 2020, 12, 5835. [CrossRef]

98. Zhong, Y.; Hu, J.; Xia, Q.; Zhang, S.; Li, X.; Pan, X.; Zhao, R.; Wang, R.; Yan, W.; Shangguan, Z.; et al. Soil microbial mechanisms promoting ultrahigh rice yield. Soil Biol. Biochem. 2020, 143, 107741. [CrossRef]

99. Priya, H.; Prasanna, R.; Ramakrishnan, B.; Bidyarani, N.; Babu, S.; Thapa, S.; Renuka, N. Influence of cyanobacterial inoc-ulation on the culturable microbiome and growth of rice. Microbiol. Res. 2015, 171, 78-89. [CrossRef] 